\title{
Synthetic, Register-Specific, AAB Heterotrimers to Investigate Single Point Glycine Mutations in Osteogenesis Imperfecta
}

\author{
Amanda M. Acevedo-Jakeff and Katherine A. Clements.t, and Jeffrey D. Hartgerink*
}

Departments of Chemistry and Bioengineering, Rice University, 6100 Main St. Houston, Texas 77005, United States

\section{Supporting Information}

\begin{tabular}{|c|c|c|c|c|}
\hline Isotopic Label & Partner Atom & Partner Residue & Type & $\begin{array}{l}\text { Standard } \\
\text { Deviation }\end{array}$ \\
\hline $45 B$ & $2 \mathrm{HA}$ & $45 B$ & positive & 1 \\
\hline $45 B$ & $1 \mathrm{HA}$ & $45 \mathrm{~B}$ & positive & 1 \\
\hline $45 \mathrm{~B}$ & $1 \mathrm{HB}$ & $72 \mathrm{C}$ & positive & 1 \\
\hline $45 B$ & $1 \mathrm{HD}$ & $14 \mathrm{~A}$ & positive & 1 \\
\hline $75 \mathrm{C}$ & $\mathrm{HA}$ & $74 \mathrm{C}$ & positive & 1 \\
\hline $75 \mathrm{C}$ & $\mathrm{H}$ & $76 \mathrm{C}$ & positive & 1 \\
\hline $75 \mathrm{C}$ & $1 \mathrm{HA}$ & $75 \mathrm{C}$ & positive & 1 \\
\hline $75 \mathrm{C}$ & $1 \mathrm{HA}$ & $18 \mathrm{~A}$ & positive & 1 \\
\hline $75 \mathrm{C}$ & $1 \mathrm{HD}$ & $19 \mathrm{~A}$ & positive & 1 \\
\hline $75 \mathrm{C}$ & $1 \mathrm{HD}$ & $44 \mathrm{~B}$ & positive & 1 \\
\hline $75 \mathrm{C}$ & $1 \mathrm{HA}$ & $45 \mathrm{~B}$ & positive & 1 \\
\hline $66 \mathrm{C}$ & $\mathrm{HA}$ & $65 \mathrm{C}$ & positive & 1 \\
\hline $66 \mathrm{C}$ & $2 \mathrm{HA}$ & $66 \mathrm{C}$ & positive & 1 \\
\hline $66 \mathrm{C}$ & $1 \mathrm{HA}$ & $66 \mathrm{C}$ & positive & 1 \\
\hline $66 \mathrm{C}$ & $1 \mathrm{HD}$ & $67 \mathrm{C}$ & positive & 1 \\
\hline $66 C$ & $1 \mathrm{HD}$ & $37 \mathrm{~B}$ & positive & 1 \\
\hline $66 \mathrm{C}$ & $2 \mathrm{HB}$ & $65 \mathrm{C}$ & positive & 1 \\
\hline $66 \mathrm{C}$ & $1 \mathrm{HB}$ & $37 \mathrm{~B}$ & positive & 1 \\
\hline $66 \mathrm{C}$ & $1 \mathrm{HB}$ & $65 \mathrm{C}$ & positive & 1 \\
\hline $66 \mathrm{C}$ & $1 \mathrm{HD}$ & $38 \mathrm{~B}$ & positive & 1 \\
\hline $15 \mathrm{~A}$ & $1 \mathrm{HA}$ & $15 \mathrm{~A}$ & positive & 1 \\
\hline $15 \mathrm{~A}$ & $2 \mathrm{HA}$ & $45 \mathrm{~B}$ & positive & 1 \\
\hline $15 \mathrm{~A}$ & $1 \mathrm{HD}$ & $43 \mathrm{~B}$ & positive & 1 \\
\hline $15 \mathrm{~A}$ & $1 \mathrm{HB}$ & $72 \mathrm{C}$ & negative & 0.75 \\
\hline $15 \mathrm{~A}$ & $2 \mathrm{HB}$ & $72 \mathrm{C}$ & negative & 0.75 \\
\hline $15 \mathrm{~A}$ & $3 \mathrm{HB}$ & $72 \mathrm{C}$ & negative & 0.75 \\
\hline $45 B$ & $\mathrm{HA}$ & $72 \mathrm{C}$ & negative & 0.75 \\
\hline $45 \mathrm{~B}$ & $\mathrm{HA}$ & $74 \mathrm{C}$ & negative & 0.75 \\
\hline $15 \mathrm{~A}$ & $\mathrm{HA}$ & 44B & negative & 0.75 \\
\hline $15 \mathrm{~A}$ & $\mathrm{HA}$ & $16 \mathrm{~A}$ & negative & 0.75 \\
\hline $15 \mathrm{~A}$ & $\mathrm{HA}$ & $71 \mathrm{C}$ & negative & 0.75 \\
\hline
\end{tabular}

Table S1. Constraints used for B-Ala modeling. 


\begin{tabular}{|c|c|c|c|c|}
\hline Isotopic Label & Partner Atom & Partner Residue & Type & $\begin{array}{l}\text { Standard } \\
\text { Deviation }\end{array}$ \\
\hline $75 C$ & $1 \mathrm{HB}$ & $74 C$ & positive & 1 \\
\hline $75 C$ & $1 \mathrm{HA}$ & $75 C$ & positive & 1 \\
\hline $75 C$ & $1 \mathrm{HB}$ & $76 C$ & positive & 1 \\
\hline $75 \mathrm{C}$ & $2 \mathrm{HB}$ & $76 \mathrm{C}$ & positive & 1 \\
\hline $75 C$ & $1 \mathrm{HD}$ & $19 A$ & positive & 1 \\
\hline $15 \mathrm{~A}$ & $2 \mathrm{HB}$ & $72 \mathrm{C}$ & positive & 0.5 \\
\hline $15 \mathrm{~A}$ & $1 \mathrm{HD}$ & $14 \mathrm{~A}$ & positive & 1 \\
\hline $15 \mathrm{~A}$ & $1 \mathrm{HA}$ & $15 \mathrm{~A}$ & positive & 1 \\
\hline $66 \mathrm{C}$ & $\mathrm{H}$ & $8 \mathrm{~A}$ & positive & 1 \\
\hline $66 C$ & $\mathrm{HA}$ & $8 \mathrm{~A}$ & positive & 1 \\
\hline $66 C$ & $1 \mathrm{HB}$ & $8 \mathrm{~A}$ & positive & 1 \\
\hline $66 C$ & $1 \mathrm{HD}$ & $8 \mathrm{~A}$ & positive & 1 \\
\hline $66 C$ & $1 \mathrm{HB}$ & $65 C$ & positive & 1 \\
\hline $66 C$ & $1 \mathrm{HA}$ & $66 C$ & positive & 1 \\
\hline $66 C$ & $2 \mathrm{HA}$ & $66 C$ & positive & 1 \\
\hline $45 \mathrm{~B}$ & $\mathrm{H}$ & $72 \mathrm{C}$ & positive & 0.5 \\
\hline $45 \mathrm{~B}$ & $\mathrm{HG}$ & $72 C$ & positive & 1 \\
\hline $45 \mathrm{~B}$ & $1 \mathrm{HD}$ & $73 C$ & positive & 1 \\
\hline $45 \mathrm{~B}$ & $\mathrm{HA}$ & $74 C$ & positive & 1 \\
\hline $45 \mathrm{~B}$ & $1 \mathrm{HB}$ & $74 C$ & positive & 0.5 \\
\hline $45 \mathrm{~B}$ & $\mathrm{H}$ & $75 \mathrm{C}$ & positive & 1 \\
\hline $45 \mathrm{~B}$ & $1 \mathrm{HA}$ & $75 \mathrm{C}$ & positive & 0.25 \\
\hline $45 B$ & $1 \mathrm{HA}$ & $15 \mathrm{~A}$ & positive & 1 \\
\hline $45 \mathrm{~B}$ & $\mathrm{H}$ & $44 \mathrm{~B}$ & positive & 1 \\
\hline $45 \mathrm{~B}$ & $\mathrm{HA}$ & 44B & positive & 1 \\
\hline $45 \mathrm{~B}$ & $1 \mathrm{HA}$ & 45B & positive & 1 \\
\hline $45 \mathrm{~B}$ & $2 \mathrm{HA}$ & $45 B$ & positive & 1 \\
\hline $66 C$ & $\mathrm{HA}$ & $37 \mathrm{~B}$ & negative & 1 \\
\hline $66 C$ & $\mathrm{HA}$ & $67 C$ & negative & 1 \\
\hline $66 C$ & $\mathrm{HA}$ & $7 \mathrm{~A}$ & negative & 1 \\
\hline $75 C$ & $\mathrm{HA}$ & $73 \mathrm{C}$ & negative & 1 \\
\hline $75 C$ & $\mathrm{HA}$ & $77 \mathrm{C}$ & negative & 1 \\
\hline $75 C$ & $\mathrm{HA}$ & $19 A$ & negative & 1 \\
\hline $15 \mathrm{~A}$ & $\mathrm{HA}$ & $71 \mathrm{C}$ & negative & 1 \\
\hline $15 \mathrm{~A}$ & $\mathrm{HA}$ & $73 C$ & negative & 1 \\
\hline $15 \mathrm{~A}$ & $\mathrm{HA}$ & $74 C$ & negative & 1 \\
\hline $45 B$ & $\mathrm{HA}$ & 47B & negative & 1 \\
\hline
\end{tabular}

Table S2. Constraints used for B-Ser modeling. 


\begin{tabular}{|c|c|c|c|c|}
\hline Isotopic Label & Partner Atom & Partner Residue & Type & $\begin{array}{l}\text { Standard } \\
\text { Deviation }\end{array}$ \\
\hline $45 \mathrm{~B}$ & $\mathrm{HA}$ & $44 \mathrm{~B}$ & positive & 1 \\
\hline $45 B$ & $2 \mathrm{HA}$ & $45 B$ & positive & 1 \\
\hline $45 \mathrm{~B}$ & $1 \mathrm{HA}$ & $45 B$ & positive & 1 \\
\hline $45 \mathrm{~B}$ & $1 \mathrm{HB}$ & $44 \mathrm{~B}$ & positive & 1 \\
\hline $45 \mathrm{~B}$ & $1 \mathrm{HD}$ & $14 \mathrm{~A}$ & positive & 1 \\
\hline $75 C$ & $\mathrm{HA}$ & $74 \mathrm{C}$ & positive & 1 \\
\hline $75 C$ & $1 \mathrm{HA}$ & $75 C$ & positive & 1 \\
\hline $75 \mathrm{C}$ & $\mathrm{HA}$ & $16 \mathrm{~A}$ & positive & 1 \\
\hline $75 \mathrm{C}$ & $1 \mathrm{HA}$ & $45 \mathrm{~B}$ & positive & 1 \\
\hline $75 C$ & $1 \mathrm{HB}$ & $74 \mathrm{C}$ & positive & 1 \\
\hline $75 C$ & $1 \mathrm{HB}$ & $44 \mathrm{~B}$ & positive & 1 \\
\hline $75 C$ & $\mathrm{H}$ & $46 B$ & positive & 1 \\
\hline $75 \mathrm{C}$ & $\mathrm{H}$ & $18 \mathrm{~A}$ & positive & 1 \\
\hline $66 C$ & $\mathrm{HA}$ & $65 C$ & positive & 1 \\
\hline $66 C$ & $\mathrm{HA}$ & $8 \mathrm{~A}$ & positive & 1 \\
\hline $66 C$ & $2 \mathrm{HA}$ & $66 C$ & positive & 1 \\
\hline $66 C$ & $1 \mathrm{HA}$ & $66 C$ & positive & 1 \\
\hline $66 C$ & $2 \mathrm{HD}$ & $67 C$ & positive & 1 \\
\hline $66 C$ & $1 \mathrm{HD}$ & $7 \mathrm{~A}$ & positive & 1 \\
\hline $66 C$ & $1 \mathrm{HD}$ & $67 C$ & positive & 1 \\
\hline $66 C$ & $2 \mathrm{HB}$ & $65 C$ & positive & 1 \\
\hline $66 C$ & $1 \mathrm{HB}$ & $65 C$ & positive & 1 \\
\hline $66 C$ & $\mathrm{H}$ & $8 \mathrm{~A}$ & positive & 1 \\
\hline $66 C$ & $\mathrm{H}$ & $36 \mathrm{~B}$ & positive & 1 \\
\hline $15 \mathrm{~A}$ & $\mathrm{HA}$ & 44B & positive & 1 \\
\hline $15 \mathrm{~A}$ & $1 \mathrm{HA}$ & $72 \mathrm{C}$ & positive & 1 \\
\hline $15 \mathrm{~A}$ & $2 \mathrm{HA}$ & $45 B$ & positive & 1 \\
\hline $15 \mathrm{~A}$ & $1 \mathrm{HD}$ & $43 B$ & positive & 1 \\
\hline $15 \mathrm{~A}$ & $1 \mathrm{HB}$ & $73 C$ & positive & 1 \\
\hline $15 \mathrm{~A}$ & $2 \mathrm{HB}$ & $44 \mathrm{~B}$ & positive & 1 \\
\hline $15 \mathrm{~A}$ & $1 \mathrm{HB}$ & $44 \mathrm{~B}$ & positive & 1 \\
\hline $66 C$ & $1 \mathrm{HA}$ & $9 A$ & negative & 1 \\
\hline $66 C$ & $\mathrm{HA}$ & $35 \mathrm{~B}$ & negative & 1 \\
\hline $15 \mathrm{~A}$ & $\mathrm{HA}$ & $17 \mathrm{~A}$ & negative & 1 \\
\hline $15 \mathrm{~A}$ & $\mathrm{HA}$ & $74 \mathrm{C}$ & negative & 1 \\
\hline $45 \mathrm{~B}$ & $1 \mathrm{HA}$ & $18 \mathrm{~A}$ & negative & 1 \\
\hline $75 C$ & $1 \mathrm{HA}$ & $15 \mathrm{~A}$ & negative & 1 \\
\hline $75 C$ & $\mathrm{HA}$ & $47 \mathrm{~B}$ & negative & 1 \\
\hline $75 \mathrm{C}$ & $\mathrm{HA}$ & $76 C$ & negative & 1 \\
\hline
\end{tabular}

Table S3. Constraints used for the Base modeling.

\begin{tabular}{ccc}
\hline $\begin{array}{c}\text { Alpha homotrimer } \\
\text { peak }\end{array}$ & T1 & T2 \\
\hline A1 & $0.459 \pm 0.031$ & $0.032 \pm 0.008$ \\
A2 & $0.522 \pm 0.042$ & $0.050 \pm 0.009$ \\
A3 & $0.399 \pm 0.041$ & $0.060 \pm 0.011$ \\
\hline
\end{tabular}

Table S4. Alpha homotrimer relaxation values. 


\begin{tabular}{llc}
\hline \multicolumn{1}{c}{ Monomer } & \multicolumn{1}{c}{ T1 } & T2 \\
\hline A Base M2 & $0.499 \pm 0.64$ & $0.340 \pm 0.024$ \\
B Base M1 & $0.516 \pm 0.033$ & $0.247 \pm 0.058$ \\
B-Ala M1 & $0.630 \pm 0.023$ & $0.320 \pm 0.075$ \\
B-Ser M1 & $0.620 \pm 0.023$ & $0.355 \pm 0.064$ \\
B-Ser M2 & $0.607 \pm 0.030$ & $0.340 \pm 0.063$ \\
B-Val M2 & $0.564 \pm 0.024$ & $0.294 \pm 0.034$ \\
B-Val M3 & $0.469 \pm 0.034$ & $0.201 \pm 0.033$ \\
B-Asp M2 & $0.601 \pm 0.029$ & $0.307 \pm 0.031$ \\
B-Asp M3 & $0.575 \pm 0.012$ & $0.274 \pm 0.030$ \\
B-Arg M2 & $0.521 \pm 0.057$ & $0.216 \pm 0.017$ \\
B-Arg M3 & $0.460 \pm 0.080$ & $0.218 \pm 0.015$ \\
B-Arg M4 & $0.542 \pm 0.013$ & $0.212 \pm 0.014$ \\
\hline
\end{tabular}

Table S5. Monomer relaxation values.

\begin{tabular}{cccc}
\hline Peak & Base & B-Ala & B-Ser \\
\hline G1 & 14.85 & 20.76 & 15.72 \\
G2 & 9.55 & 10.67 & 13.53 \\
G3 & 21.32 & 13.79 & 18.63 \\
G4 & 8.00 & 10.02 & 17.84 \\
\hline
\end{tabular}

Table S6. Peak volumes from $1 \mathrm{H}, 15 \mathrm{~N}-\mathrm{HSQC}$.
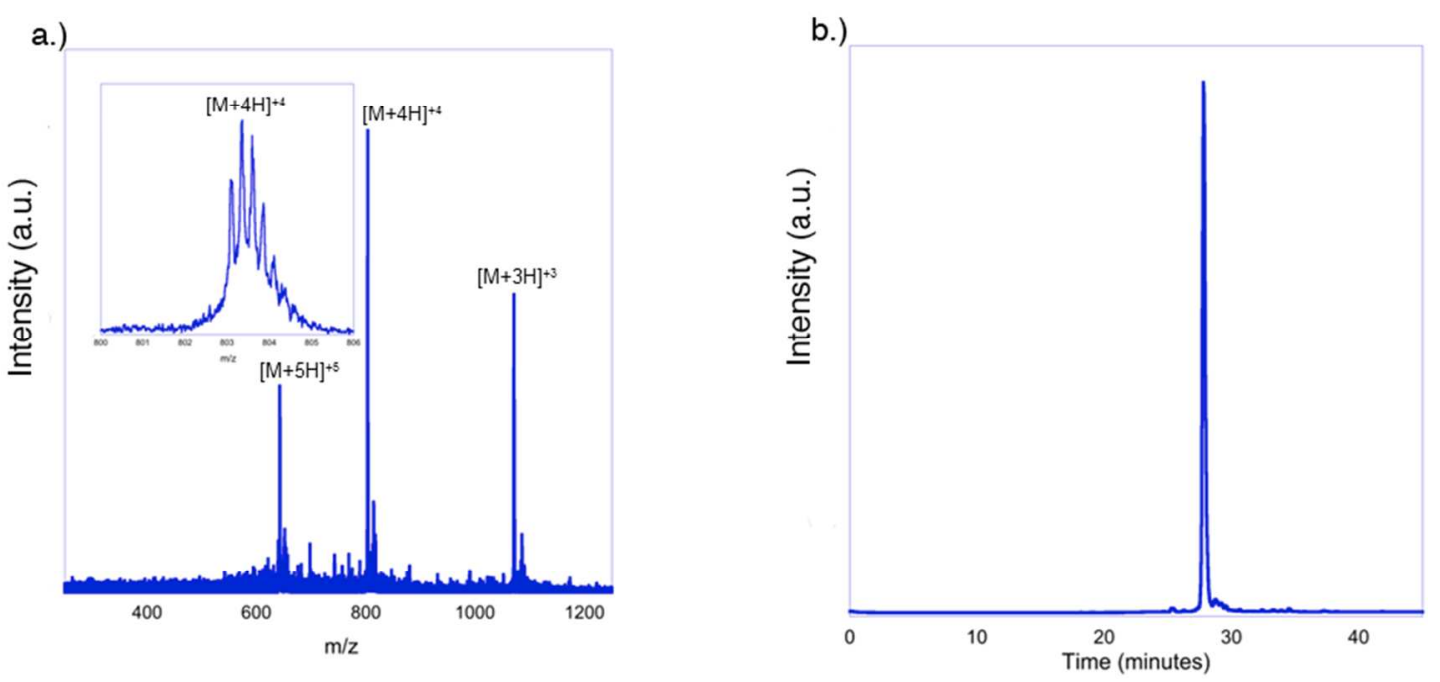

Figure S1. a) ESI-TOF MS of the purified fractions (Predicted MW $[\mathrm{M}+\mathrm{H}]^{+}=3210.55$ Observed $=3211.48$ ) and $\mathrm{b}$ ) HPLC trace of the Base A peptide. 

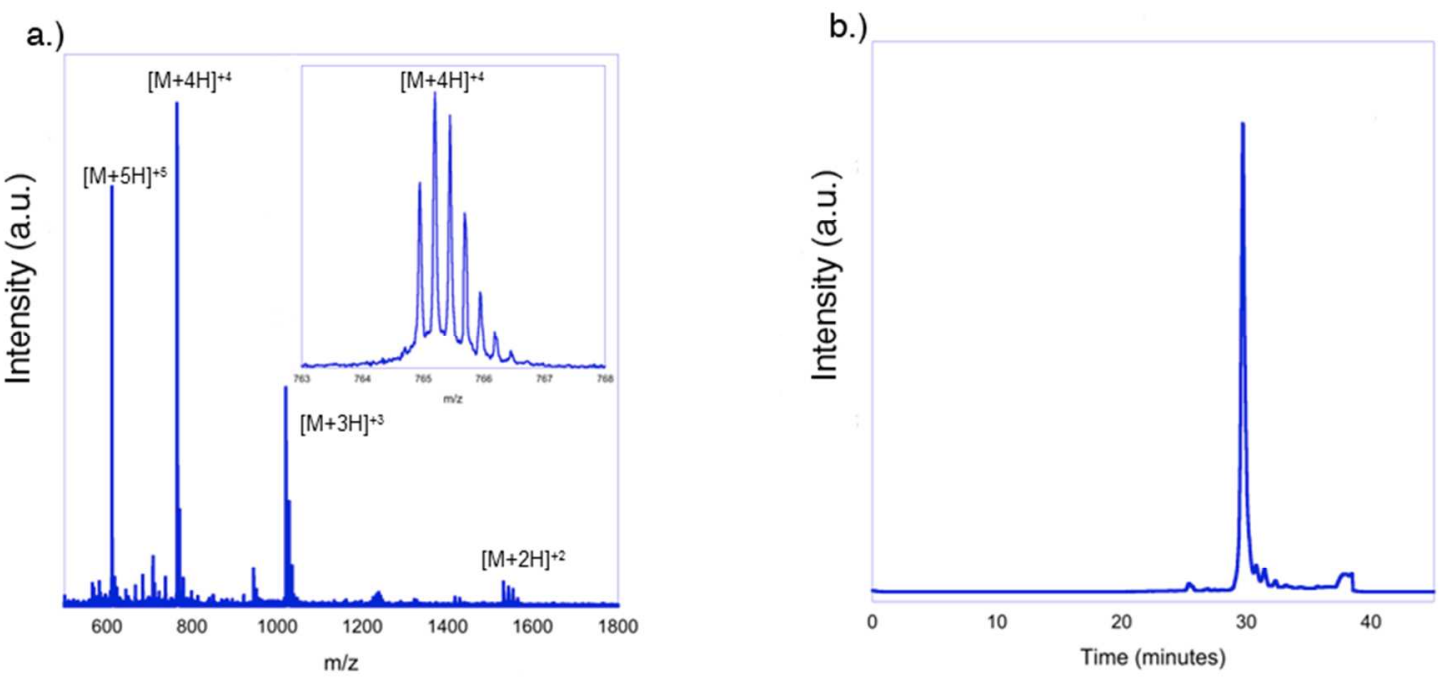

Figure S2. a) ESI-TOF MS of the purified fractions (Predicted MW $[\mathrm{M}+\mathrm{H}]^{+}=3062.23$ Observed $=3061.60)$ and $b$ ) HPLC trace of the Base B peptide.

a.)

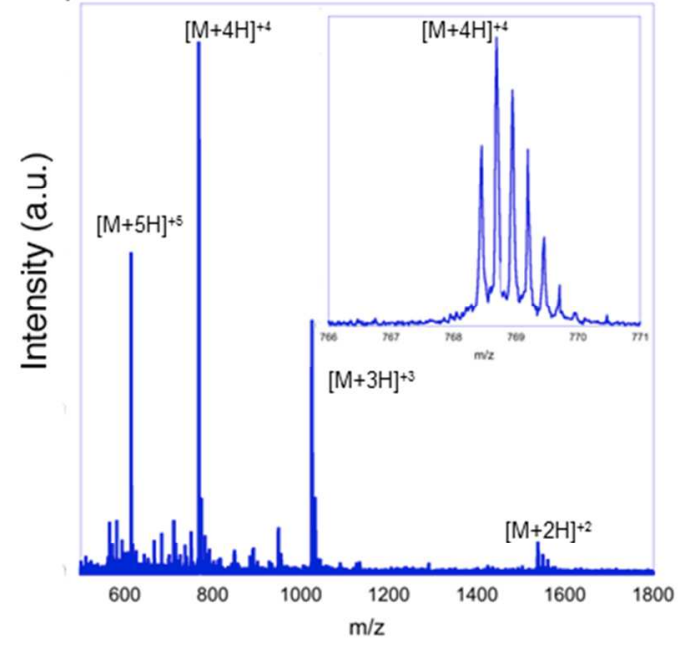

b.)

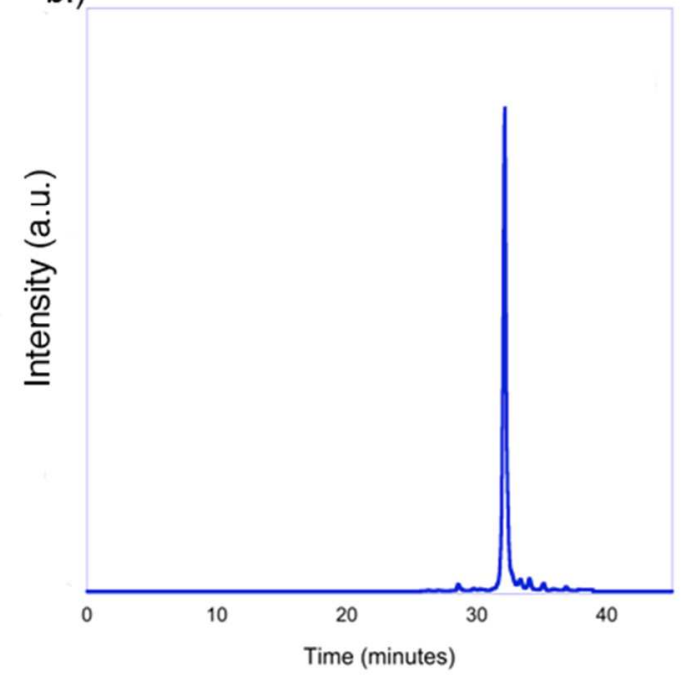

Figure S3. a) ESI-TOF MS of the purified fractions (Predicted MW $[\mathrm{M}+\mathrm{H}]^{+}=3079.25$ Observed $=3078.08$ ) and b) HPLC trace of the B-Ala B peptide. 
a.)

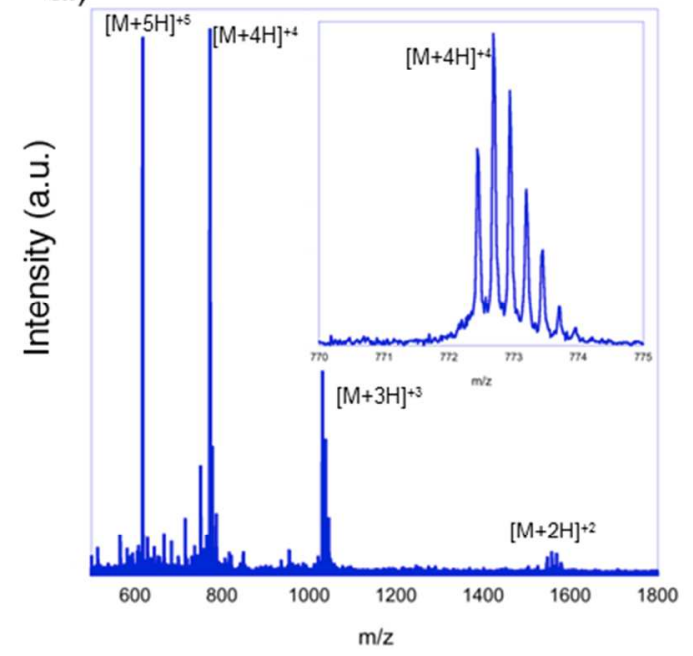

b.)

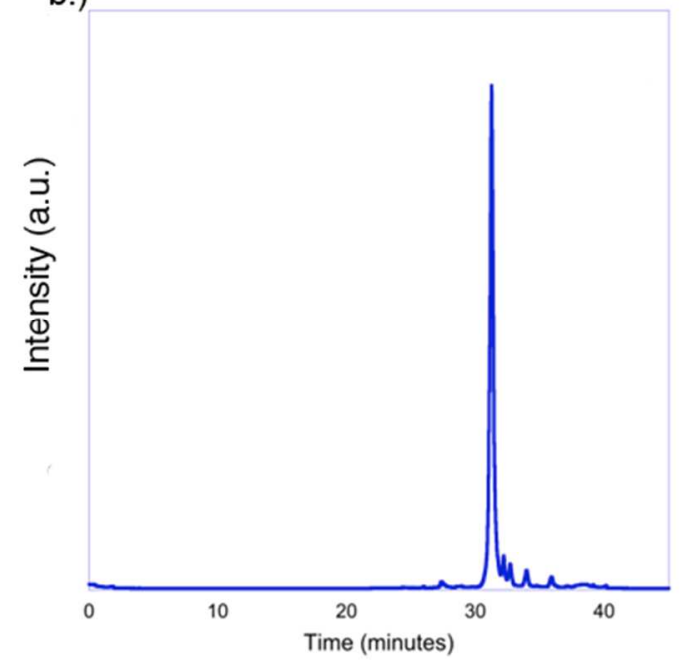

Figure S4. a) ESI-TOF MS of the purified fractions (Predicted MW $[\mathrm{M}+\mathrm{H}]^{+}=3095.23$ Observed $=3094.48$ ) and b) HPLC trace of the B-Ser B peptide.
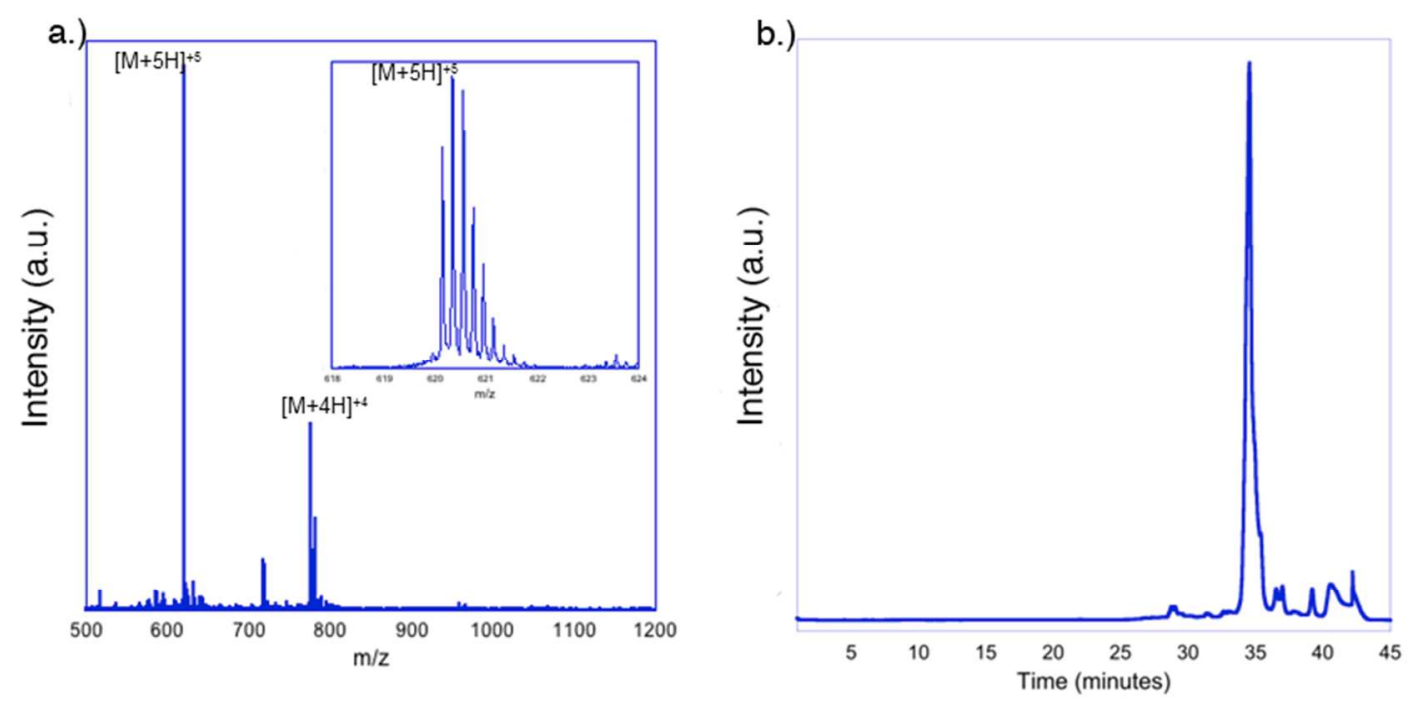

Figure S5. a) ESI-TOF MS of the purified fractions (Predicted MW $[\mathrm{M}+\mathrm{H}]^{+}=3107.12$ Observed $=3108.11)$ and $\mathrm{b}$ ) HPLC trace of the crude B-Val B peptide. 

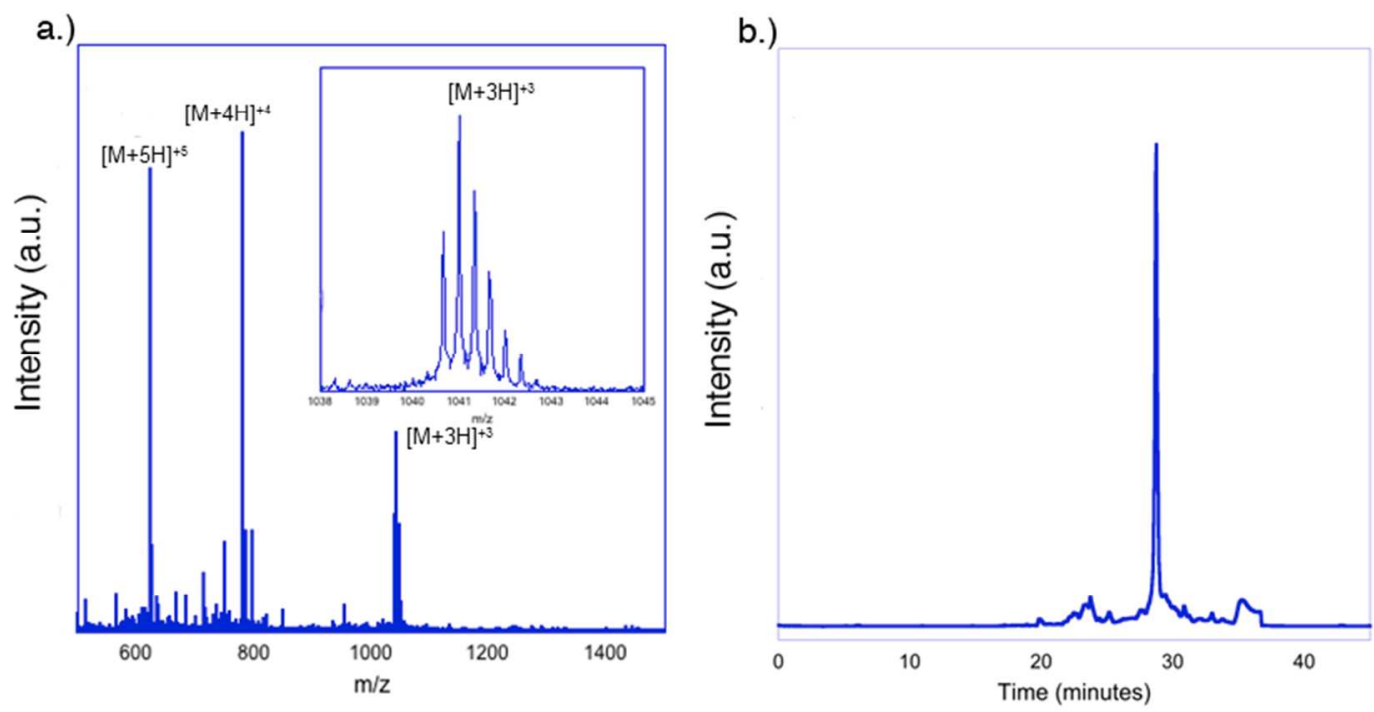

Figure S6. a) ESI-TOF MS of the purified fractions (Predicted MW $[\mathrm{M}+\mathrm{H}]^{+}=3123.08$ Observed $=3122.80$ ) and $\mathrm{b}$ ) HPLC trace of the crude B-Asp B peptide.
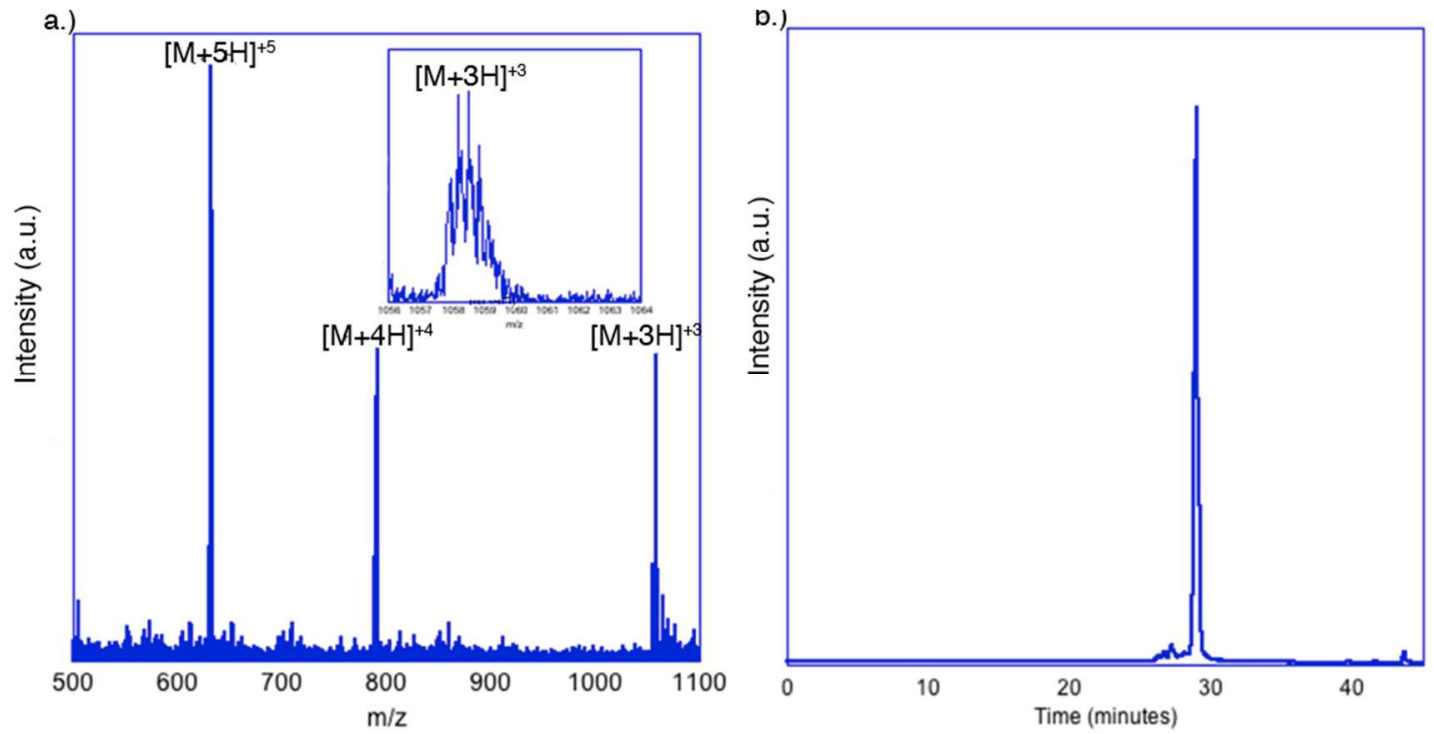

Figure S7. a) ESI-TOF MS of the purified fractions (Predicted MW $[\mathrm{M}+\mathrm{H}]^{+}=3164.10$ Observed $=3164.30$ ) and b) HPLC trace of the crude B-Arg B peptide. 


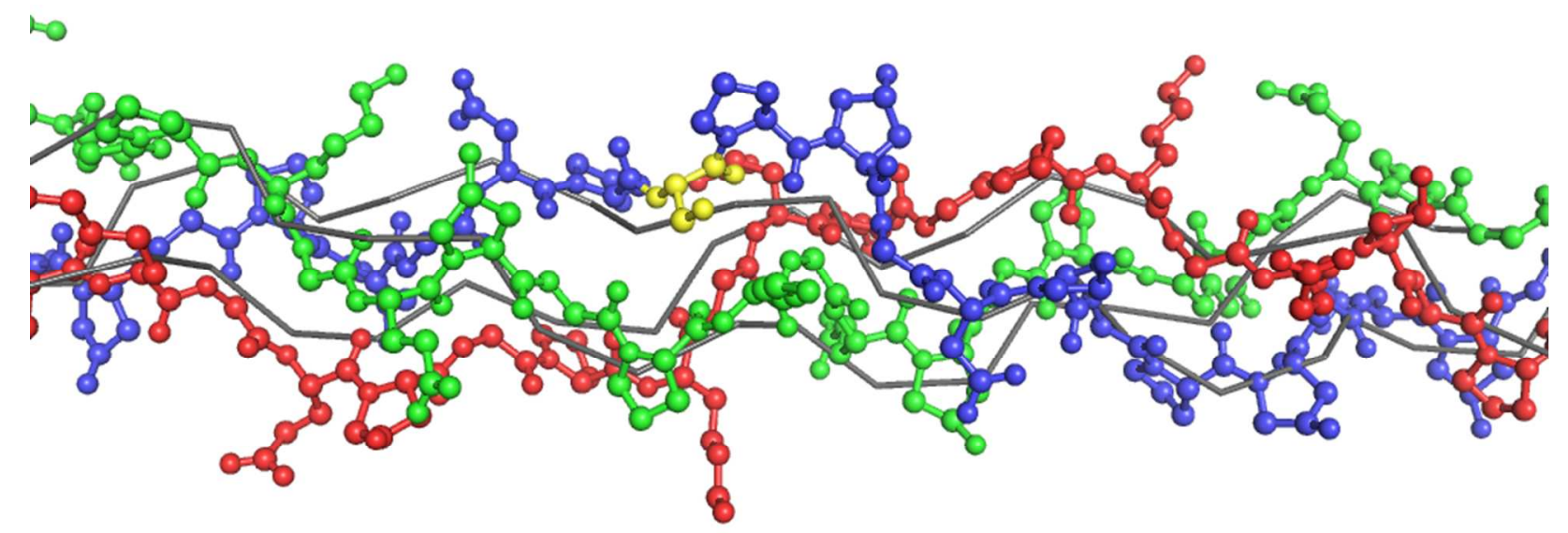

Figure S8. B-Ser model overlaid with the Base structure backbone in grey.

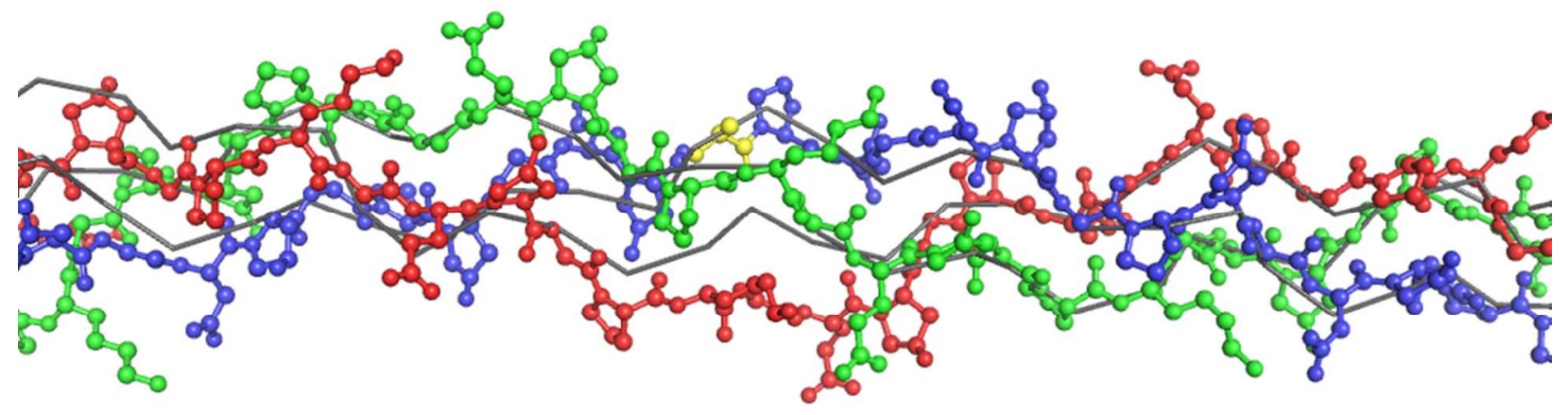

Figure S9. B-Ala model overlaid with the Base structure backbone in grey.

NMR assignments were made from a combination of the HSQC, TOCSY and NOESY HSQC data. After identifying the ${ }^{1} \mathrm{H}$ chemical shift for the $\mathrm{N}-\mathrm{H}$ peaks in the HSQC, TOCSY was used to locate the glycine alpha hydrogens. It was possible to discern Gly1 from Gly2 and Gly3 etc. by the NOESY HSQC, where the adjacent alpha hydrogen of the N-terminal residue (either lysine or hydroxyproline) helped clarify which peak corresponded to which residue. TOCSY was used to confirm these assignments (see figures below). The remaining chemical shifts from the NOESY HSQC could then be spatially mapped to a model once the chain location was determined, and the side chains unambiguously assigned to the residues surrounding the ${ }^{15} \mathrm{~N}$-glycine. 


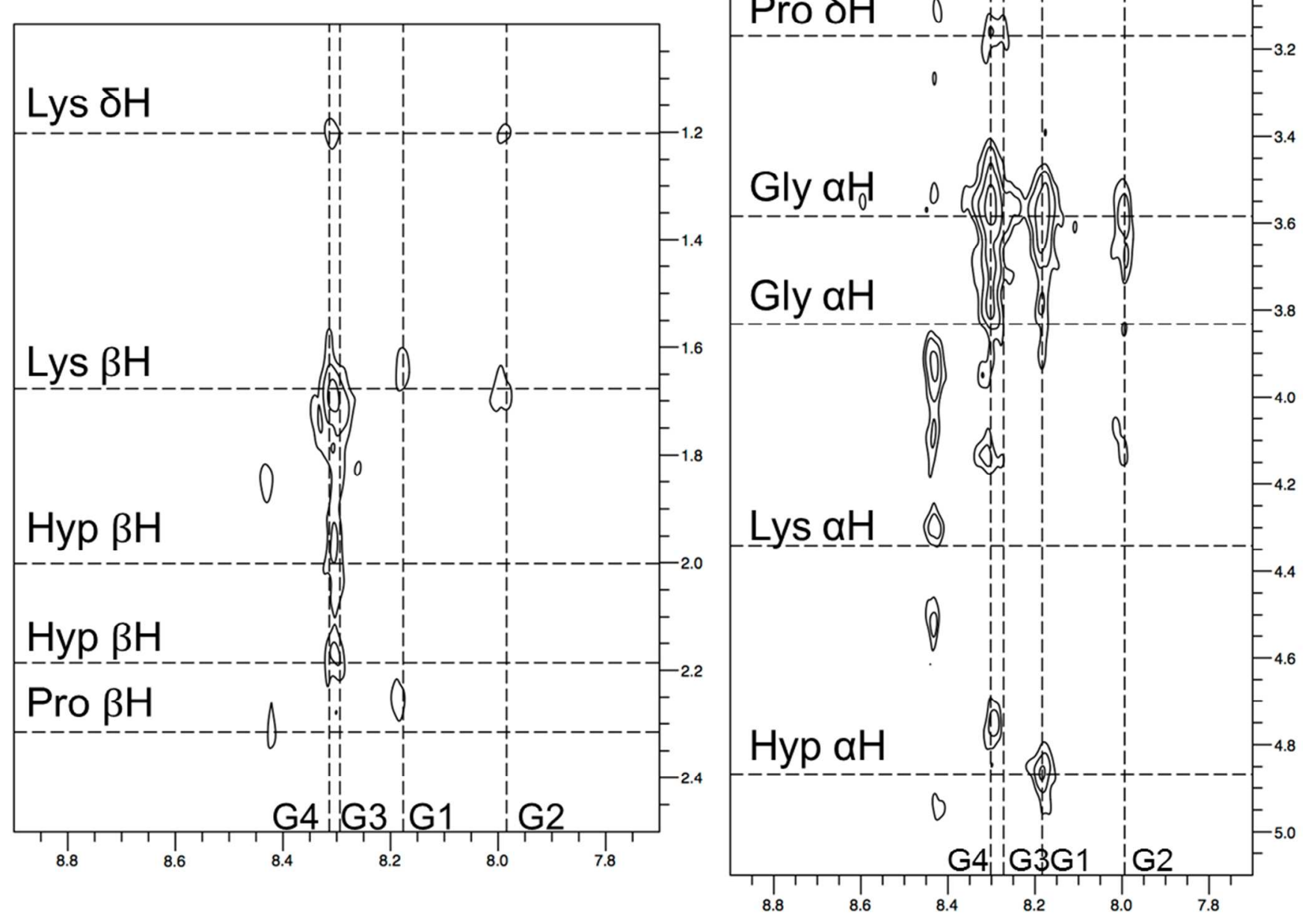

Figure S1o. NOESY HSQC of the AAB base peptide. 

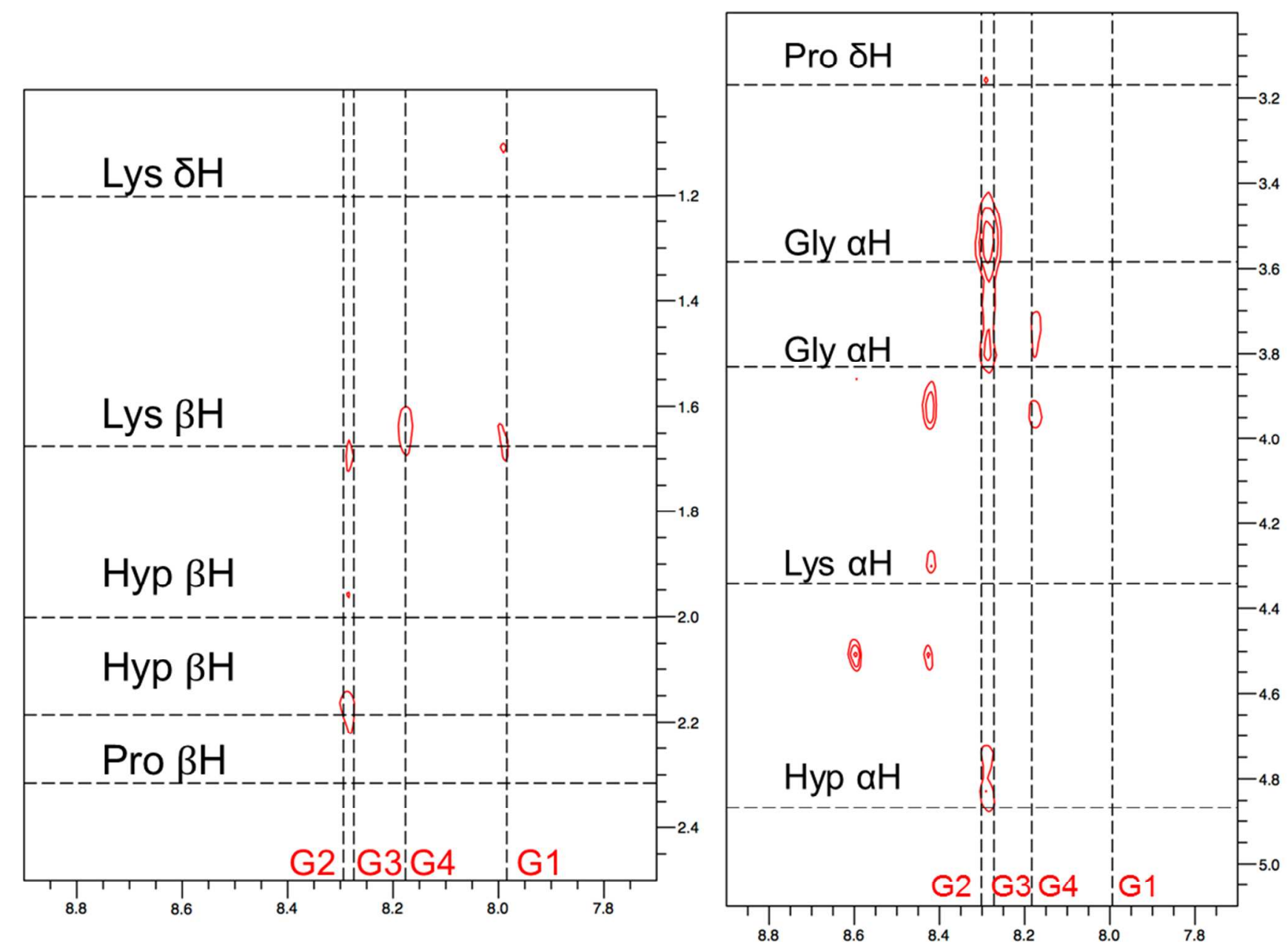

Figure S11. NOESY HSQC of the AAB' B-Ala peptide. 

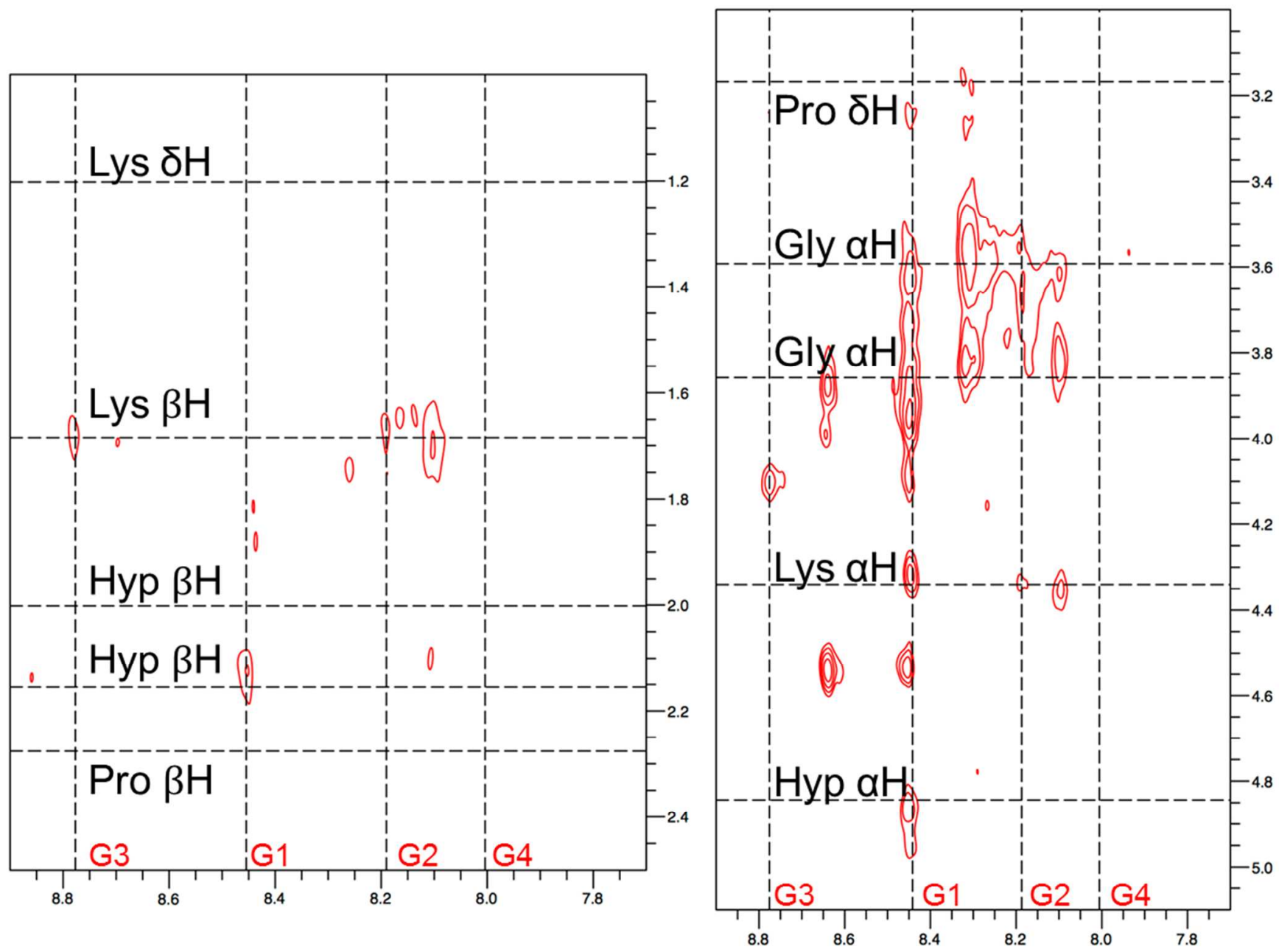

Figure S12. NOESY HSQC of the AAB' B-Ser peptide. 


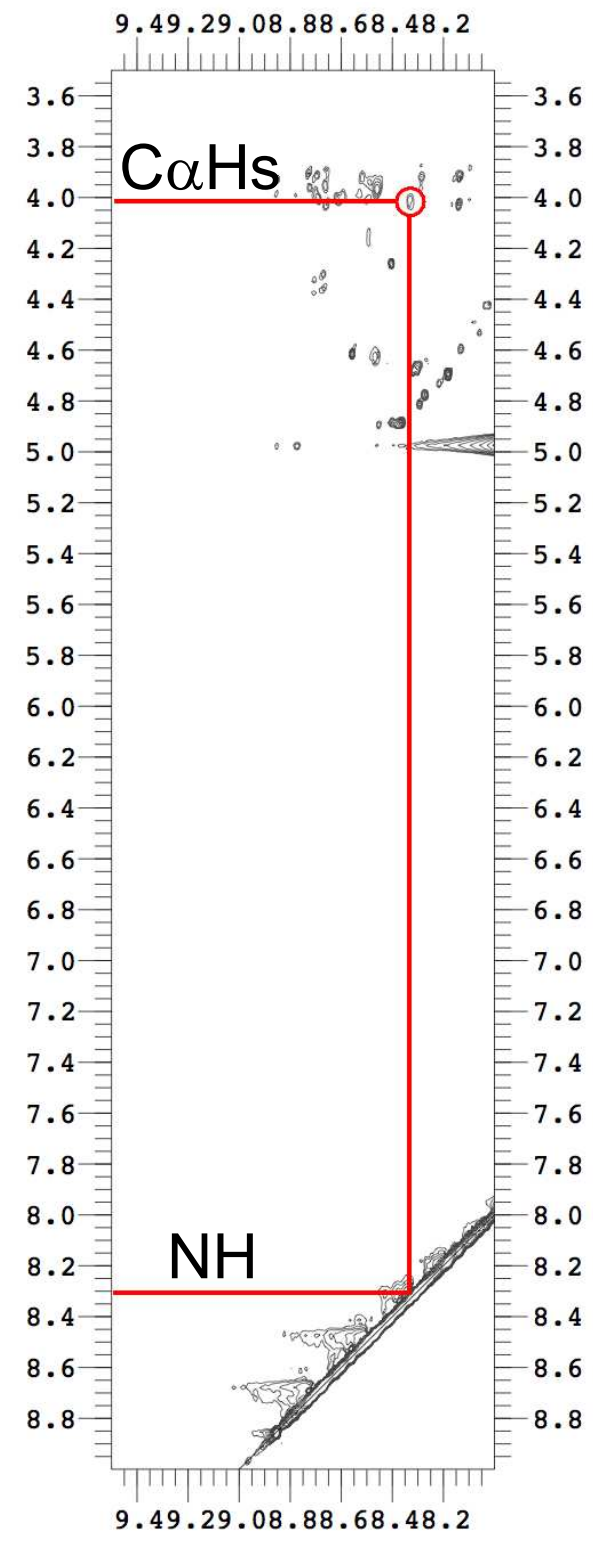

Figure S13. TOCSY figure showing connectivity for Gly3 in the Base system. Chemical shifts are shown by red lines, and relevant correlations are circled. 


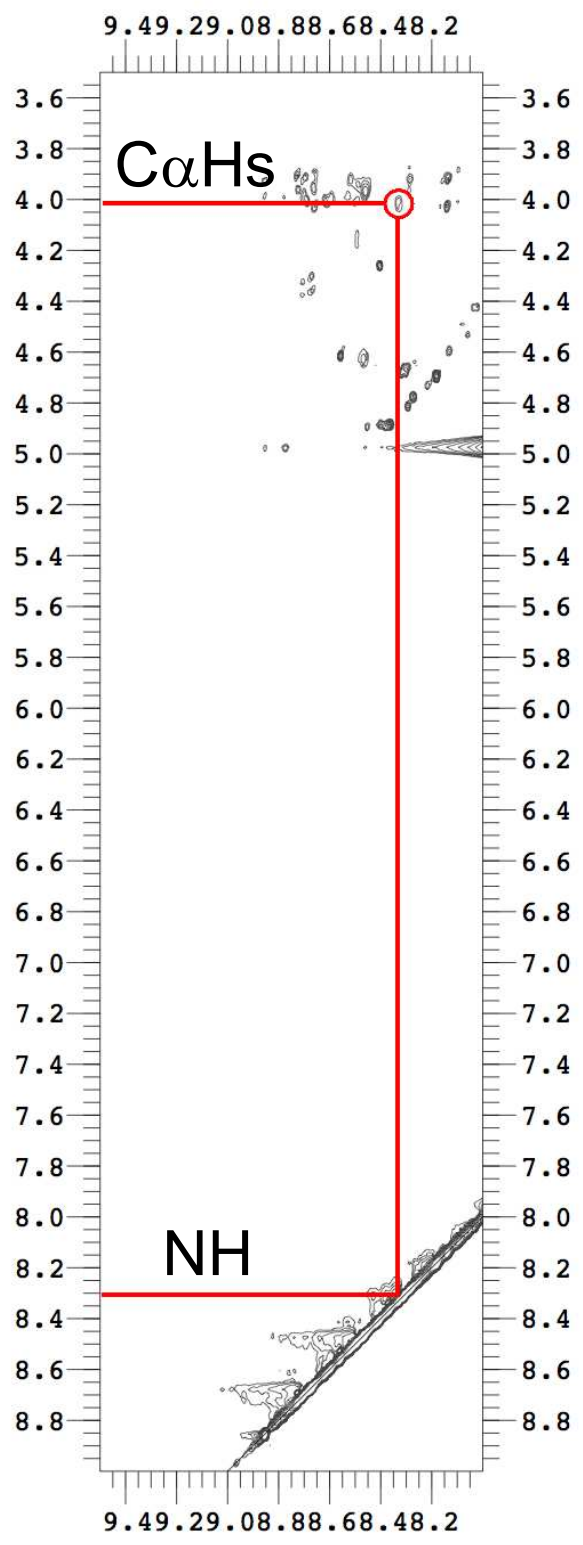

Figure S14. TOCSY figure showing connectivity for Gly3 in the B-Ala system. Chemical shifts are shown by red lines, and relevant correlations are circled. 


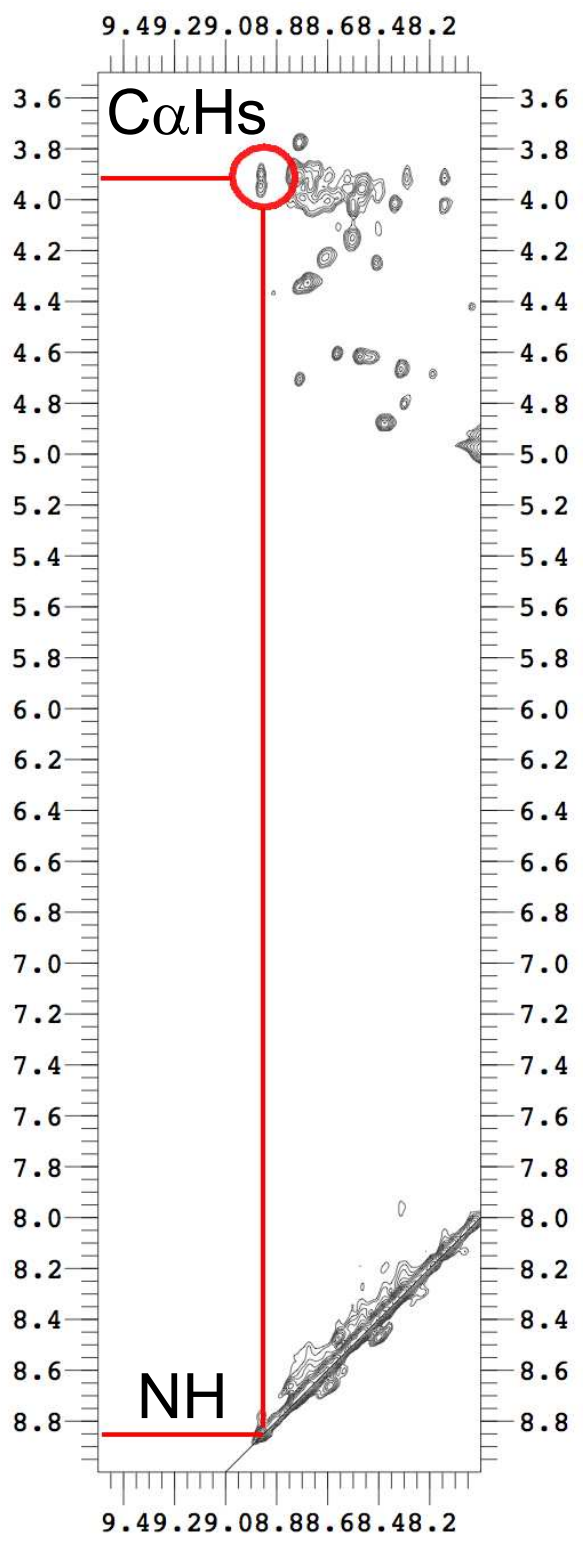

Figure S15. TOCSY figure showing connectivity for Gly3 in the B-Ser system. Chemical shifts are shown by red lines, and relevant correlations are circled. 


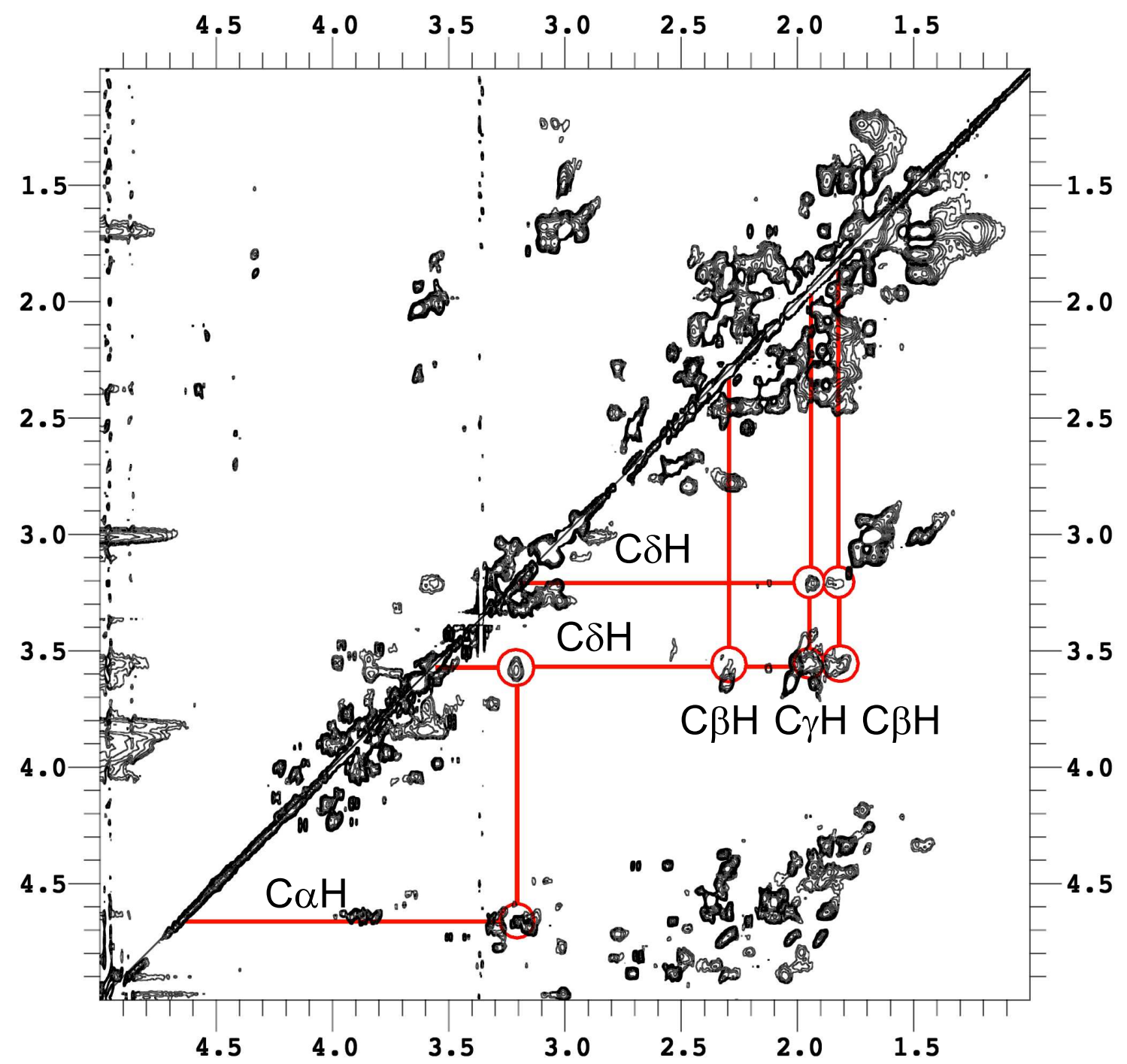

Figure S16. TOCSY figure showing connectivity for folded proline residues. Chemical shifts are shown by red lines, and relevant correlations are circled. With the mixing time used during acquisition (85 $\mathrm{ms})$ it was not possible to see direct $\mathrm{C} \beta \mathrm{H}$ to $\mathrm{C} \alpha \mathrm{H}$ correlations- for shorter mixing times (25 $\mathrm{ms}$ ) this cross peak was observed though overlapped with other peaks in the alpha proton region. Though not directly coupled, with the longer $85 \mathrm{~ms}$ mixing time it was possible to observe a $\mathrm{C} \delta \mathrm{H}$ to $\mathrm{C} \alpha \mathrm{H}$ cross peak. 


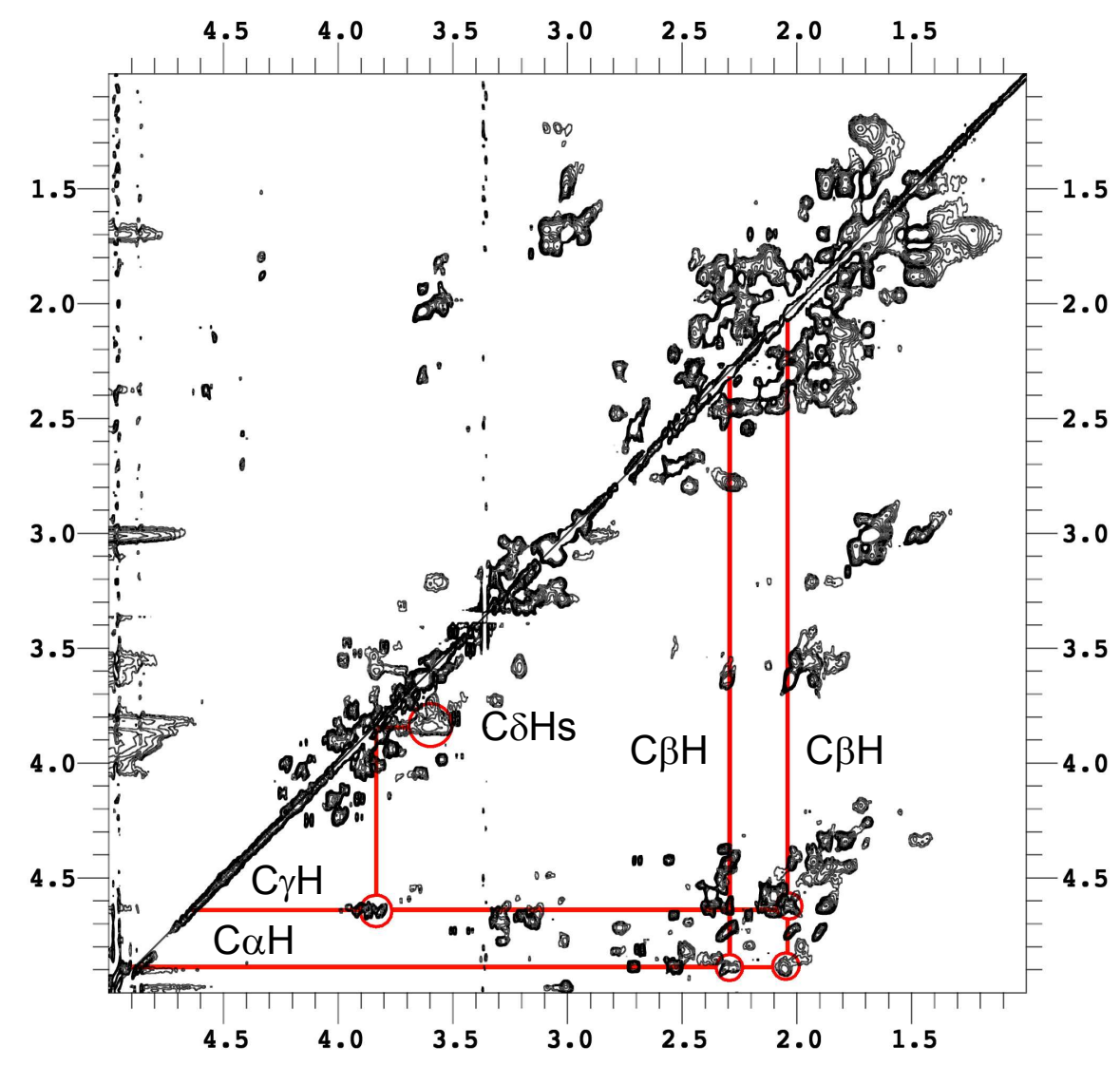

Figure S17. TOCSY figure showing connectivity for folded hydroxyproline residues. Chemical shifts are shown by red lines, and relevant correlations are circled. 


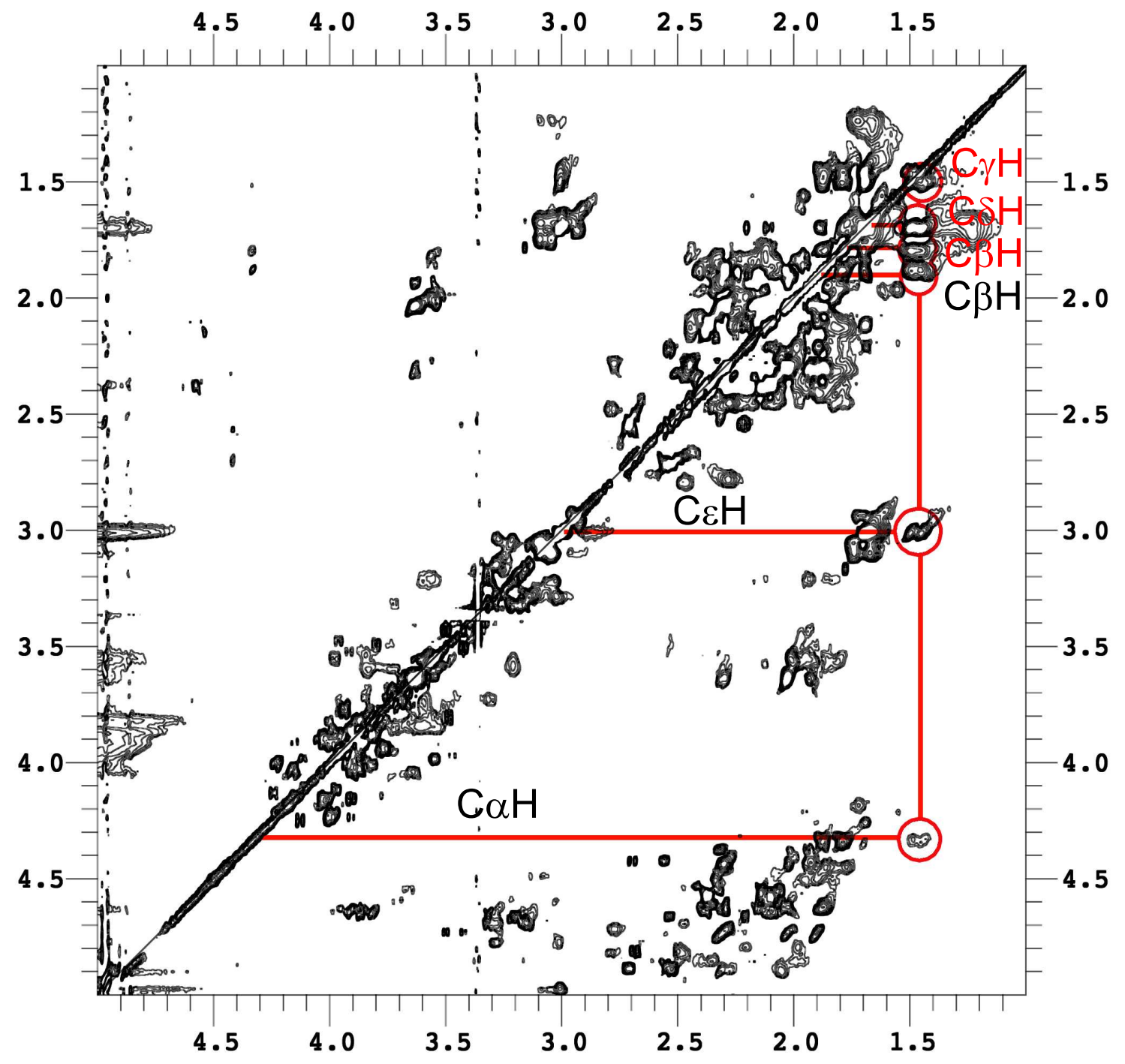

Figure S18. TOCSY figure showing connectivity for folded lysine residues. Chemical shifts are shown by red lines, and relevant correlations are circled. 


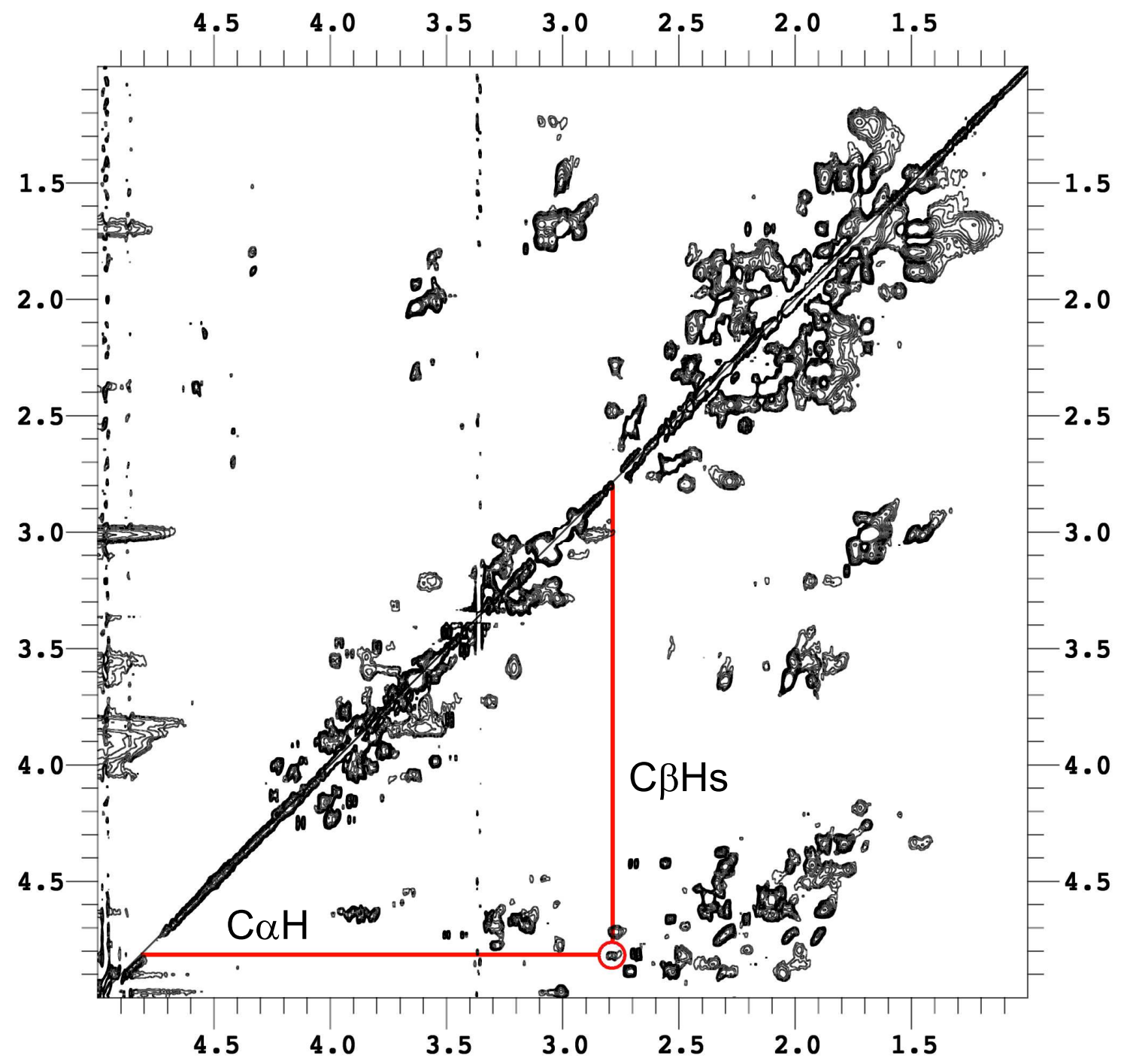

Figure S19. TOCSY figure showing connectivity for folded aspartate residues. Chemical shifts are shown by red lines, and relevant correlations are circled. 


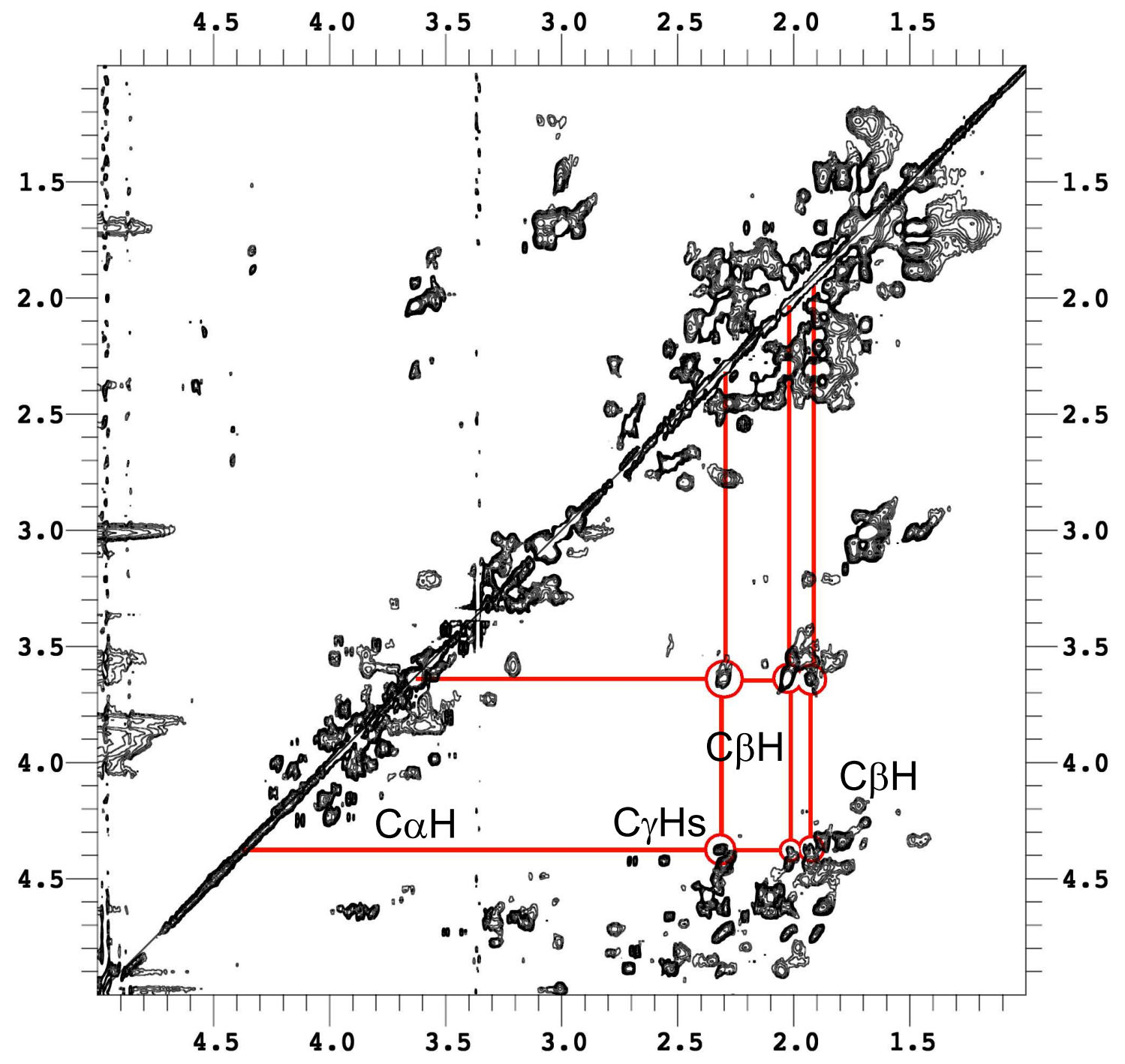

Figure S20. TOCSY figure showing connectivity for folded glutamate residues. Chemical shifts are shown by red lines, and relevant correlations are circled. 